Article

\title{
Acacia longifolia: A Host of Many Guests Even after Fire
}

\author{
Joana Guedes de Jesus ${ }^{1,2}$, Rogério Tenreiro ${ }^{3 \oplus}$, Cristina Máguas ${ }^{1, *}$ and Helena Trindade ${ }^{2}$ \\ 1 Centre for Ecology, Evolution and Environmental Changes (cE3c), Faculdade de Ciências da Universidade \\ de Lisboa, 1749-016 Lisboa, Portugal; jguedesj13@gmail.com \\ 2 Centro de Estudos do Ambiente e do Mar (CESAM), Faculdade de Ciências da Universidade de Lisboa, \\ 1749-016 Lisboa, Portugal; htrindade@fc.ul.pt \\ 3 Biosystems and Integrative Sciences Institute (BioISI), Faculdade de Ciências da Universidade de Lisboa, \\ 1749-016 Lisboa, Portugal; rptenreiro@fc.ul.pt \\ * Correspondence: cmhanson@fc.ul.pt
}

Received: 17 April 2020; Accepted: 17 June 2020; Published: 19 June 2020

\begin{abstract}
Acacia longifolia is a worldwide invader that cause damage in ecosystems, expanding largely after wildfires, which promote germination of a massive seed bank. As a legume, symbiosis is determinant for adaptation. Our study aims to isolate a wider consortium of bacteria harboured in nodules, including both nitrogen and non-nitrogen fixers. Furthermore, we aim to evaluate the effects of fire in nodulation and bacterial diversity on young acacias growing in unburnt and burnt zones, one year after the fire. For this, we used molecular approaches, M13 fingerprinting and $16 \mathrm{~S}$ rRNA partial sequencing, to identify species/genera involved and $\delta^{15} \mathrm{~N}$ isotopic composition in leaves and plant nodules. Nitrogen isotopic analyses in leaves suggest that in unburnt zones, nitrogen fixation contributes more to plant nitrogen content. Overall, A. longifolia seems to be promiscuous and despite Bradyrhizobium spp. dominance, Paraburkholderia spp. followed by Pseudomonas spp. was also found. Several species not previously reported as nitrogen-fixers were identified, proposing other functions besides ammonia acquisition. Our study shows that bacterial communities are different in nodules after fire. Fire seems to potentiate nodulation and drives symbiosis towards nitrogen-fixers. Taken together, a multifunctional community inside nodules is pointed out which potentiate A. longifolia invasiveness and adaptation.
\end{abstract}

Keywords: climate change; invasive species; nodulation; symbiosis; Bradyrhizobium spp.

\section{Introduction}

In a fast-changing planet and under a climate change scenario, biological invasions have become a serious problem. To overcome them, understanding species mechanisms to adapt to a new environment is crucial for biodiversity protection [1], conservation ecology and management strategies [2]. Exotic species introduction and outcompeting with natives can lead to invasion [3], due to their ability to easily adapt to new environments. One of the largest and widespread families of flowering plants is Fabaceae, which includes species that are becoming major threats for biodiversity [4].

Acacia is one of such genera and it constitutes a polyphyletic group comprising over 1350 species [5], the majority native to Australia [6]. Several acacias have been introduced outside Australia and have resulted in invasive populations worldwide, present at a higher frequency in Mediterranean climates like California, the Iberian Peninsula, and South Africa [7]. Acacia longifolia (Andrews) Willd. (Sidney golden wattle) is considered nowadays one of the most aggressive species worldwide as well as one of the most interesting invaders. In Portugal, this species was introduced for dune stabilization, preservation of sand erosion and with ornamental purposes during the late nineteenth century and the 
beginning of the twentieth [8]; however, nowadays it presents an ecological concern. In fact, Acacia spp. contributes largely to the $18 \%$ of the Portuguese mainland area occupied by alien species [9]. A. longifolia has been described as an "ecosystem-engineer" [10-12], due to its specific characteristics, including: high adaptive plasticity, altering soil environment, ecosystems' functioning and diminishing local biodiversity [1], formation of a soil seed bank with a high germination rate and seedlings survival [13] and high water and resources consumption $[14,15]$. The control measures of this species are challenging and should be added as a priority in applied conservation research.

Moreover, this "engineering" is mostly determined by its inherent ability to fix atmospheric nitrogen through Legume-Rhizobia symbioses. Biological nitrogen fixation occurs inside nodules, developed in roots, which includes a complex and reciprocal signalization process between the host plant and compatible bacteria. The host plant releases flavonoids that stimulate the production of Nod factors by bacteria and triggers root invasion and nodule formation. Besides this structural development, the presence of nitrogenase complex (nif genes) is essential, allowing nitrogen fixation, and leghemoglobin responsible for microaerophilic environments as an oxygen-buffer, for nitrogenase functioning inside nodules. When everything is perfectly settled, bacteria provides usable nitrogen forms to the plant in exchange for carbohydrates [16].

Invasiveness, and its ecosystems impacts, is in fact a process highly mediated by plant-microbe interactions [17], with several gaps remaining in our knowledge on this process. Acacia spp. does not have a specific bacterial partner, and the identification of who is taking part in nodule's bacteriome remains a major challenge. Until now, several studies showed Bradyrhizobium as the most common partner in native and introduced environments, followed by Rhizobium [18], while Mesorhizobium and Sinorhizobium appear mostly in the native range [19-22]. In fact, nitrogen-fixers are among the functional and taxonomically diverse rhizosphere communities [17]. A. longifolia is a promiscuous woody species, that possibly exploits soil bacterial diversity to find partners for symbiotic success, particularly relevant in the context of invasion $[23,24]$. Studies have been focused so far on nitrogen-fixing species, with a lack of information on other partners identification.

Under climate change, fire events are becoming more frequent and are an important and crucial area to address. Fires are a common disturbance in regions with Mediterranean climates (such as Portugal and Australia) [25]. Since fire stimulates acacia seed germination [16], a burst in natural regeneration ultimately results in Acacia sp. dominance. Despite the importance of understanding young plants' invasive behaviour, particularly concerning the establishment of symbiotic interactions, no studies have been reported so far. Finding the adequate symbiotic partners can determine the success or the decline of the invader, highlighting the importance of clarifying the belowground relation between microbial communities and the invader A. longifolia. Furthermore, nodules can harbour more than nitrogen-fixing rhizobia, as has been shown by Martínez-Hidalgo and Hirsch [26], and the total diversity needs to be studied.

In this paper, (1) we aim to address the wider consortium of bacteria that nodules harbour, including bacterial communities not involved in nitrogen fixation. Additionally, (2) we hypothesise that fire could affect nodulation per se, rendering after fire root nodules' bacterial community different. With that in mind, understanding above- and belowground dynamics is a key factor to understand A. longifolia as an ecosystem transformer.

\section{Materials and Methods}

\subsection{Study Site Description and Nodules Collection}

Nodules from young A. longifolia plants were collected in Mira, Aveiro, Portugal mainland $\left(40.52451^{\circ} \mathrm{N}, 8.67253^{\circ} \mathrm{W}\right)$, one year after fire occurrence, in October of 2017. This region has a Mediterranean climate, with an Atlantic influence. In the last 30 years, annual temperatures ranged from a mean minimum of $10^{\circ} \mathrm{C}$ to a maximum of $20.2^{\circ} \mathrm{C}$ and a mean annual precipitation of $904 \mathrm{~mm}$. However, 2017 was a harsh year, registering a hot and dry Spring with the hottest April since 1931 and 
almost no precipitation registered, leading to an increasing of drought from May until beginning of the Autumn, culminating in the October fires [27].

The study site was an area occupied with forest, including Acacia sp., Eucalyptus sp. and Pinus sp. trees. Six sampling sites were selected, including three unburnt zones or zones were no fire occurred (UBZ) and three burnt zones (BZ) (Figure 1). An area of $25 \mathrm{~m}^{2}(5 \times 5$ plots) was established in each sampled zone, where eight individual young plants $(20-60 \mathrm{~cm})$ were selected randomly. Acacia nodules were collected by digging up plants to identify roots with attached nodules. Nodules were counted, their size was measured and then they were stored in silica gel and kept under room temperature until use.

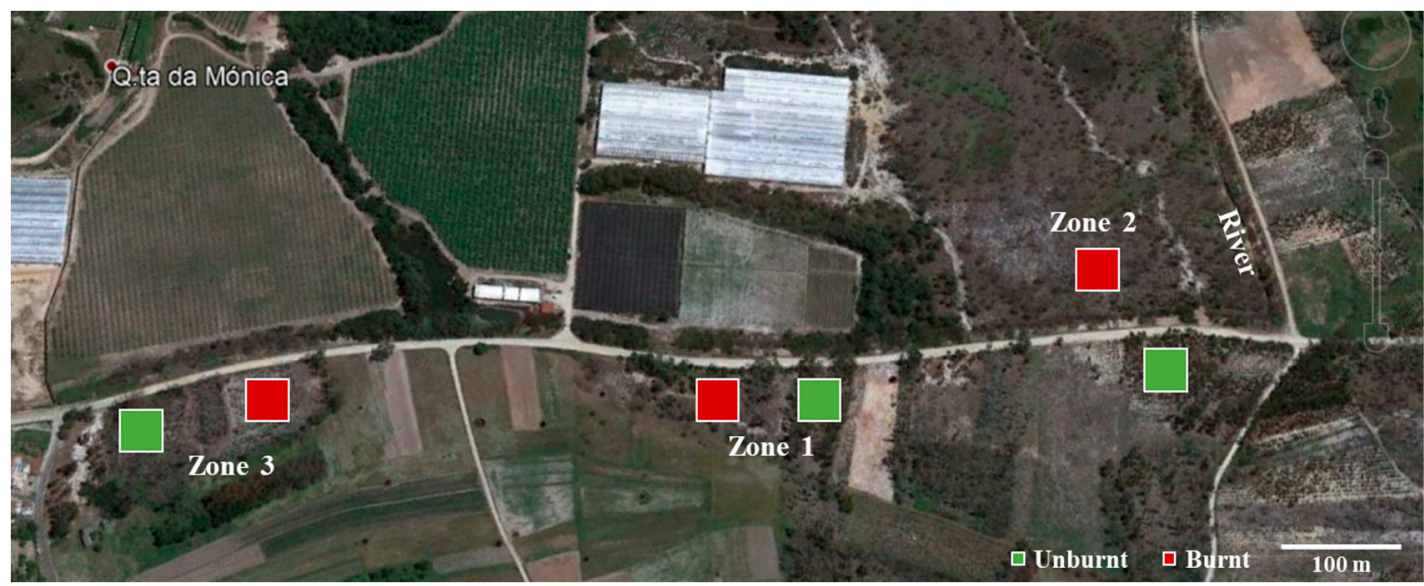

Figure 1. Schematic representation of the location of the six sampled sites: three unburnt zones (green) and three burnt zones (red). The $5 \times 5 \mathrm{~m}$ plots were established to collect young plants and nodules.

\subsection{Soil Characteristics}

Soil samples were collected from a depth of 0-20 cm after removing litter layer. A mixed sample was made through the collection of soil from three spots in each zone according to Sankhla et al. [28], and each sample was approximately $1.5 \mathrm{~kg}$. For soil analysis, three subsamples were collected and mixed in a composite sample; these samples were analysed for basic characteristics such as texture and particle size through gravimetric essays, $\mathrm{pH}$ (water and $\mathrm{KCl} 1 \mathrm{M}$ ) through a suspension method and potentiometry, organic matter $(\mathrm{OM})$ with thermic decomposition, $\mathrm{P}_{2} \mathrm{O}_{5}$ (phosphorus) and $\mathrm{K}_{2} \mathrm{O}$ (potassium oxide) and the amount of total and mineral $\mathrm{N}\left(\mathrm{N}_{-} \mathrm{NH}_{4}{ }^{+}\right.$and $\mathrm{N}^{-\mathrm{NO}_{3}}{ }^{-}$), all through molecular absorption in a segmented flux analyzer. Soil was characterized by a coarse texture in both studied zones, with a $\mathrm{pH}$ of 5.4-5.5 (Table 1). Analysis was performed by Plants and Soils Laboratory from Universidade de Trás-os-Montes e Alto Douro (UTAD), Portugal.

Table 1. Mean values of soil parameters: texture, water $\mathrm{pH}$, soil organic matter $(\mathrm{OM})(\%)$, amount of $\mathrm{P}_{2} \mathrm{O}_{5}\left(\mathrm{mg} \cdot \mathrm{kg}^{-1}\right)$, total amount of nitrogen $(\mathrm{N})\left(\mathrm{g} \cdot \mathrm{kg}^{-1}\right)$ and amount of mineral nitrogen $\left(\mathrm{mg} \cdot \mathrm{N} \cdot \mathrm{kg}^{-1}\right)$, including $\mathrm{NO}_{3}{ }^{-}$and $\mathrm{NH}_{4}{ }^{+}$. Statistically significant differences, according to $t$-test with an $\alpha=0.05$, are represented by *

\begin{tabular}{|c|c|c|c|c|c|c|c|}
\hline & \multirow{2}{*}{ Texture } & \multirow{2}{*}{ Water $\mathrm{pH}$} & \multirow{2}{*}{ OM (\%) } & \multicolumn{2}{|c|}{ Egner-Riehm Extraction } & \multicolumn{2}{|c|}{ Mineral N - N mg.kg ${ }^{-1}$} \\
\hline & & & & $\mathrm{P}_{2} \mathrm{O}_{5} \mathrm{mg} \cdot \mathrm{kg}^{-1}$ & Total N g.kg ${ }^{-1}$ & $\mathrm{~N}-\mathrm{NO}_{3}{ }^{-}$ & $\mathrm{N}-\mathrm{NH}_{4}{ }^{+}$ \\
\hline UBZ & Coarse & 5.5 & 1.02 & 3 & $0.054^{*}$ & 2.8 & 2.8 \\
\hline BZ & Coarse & 5.4 & 2.08 & 16 & 0.124 & 4.3 & 6.3 \\
\hline
\end{tabular}

\subsection{Isotopic Analysis}

Leaves and nodules from young plants were collected from the six sampled sites and were dried during $48 \mathrm{~h}$ in a drying kiln at $60{ }^{\circ} \mathrm{C}$. Each sample was ground using a ball mill and 2-2.5 mg was weighted for isotopic analysis. ${ }^{13} \mathrm{C} /{ }^{12} \mathrm{C}$ and ${ }^{15} \mathrm{~N} /{ }^{14} \mathrm{~N}$ ratios in the samples were determined using 
a continuous flow isotope mass spectrometry on a Sercon Hydra 20-22 (Sercon, Crewe, UK) stable isotope ratio mass spectrometer, coupled to a EuroEA (EuroVector, Pavia, Italy) elemental analyser for online sample preparation by Dumas-combustion. Delta $(\delta)$ calculation was performed according to $\delta=[($ Rsample - Rstandard $) /$ Rstandard $] \times 1000$, where $\mathrm{R}$ is the ratio between the heavier and lighter isotopes. $\delta^{15} \mathrm{~N}$ air values are referred to air and $\delta^{13} \mathrm{C}$ VPDB values are referred to PDB (Pee Dee Belemnite). The (secondary) reference materials used were Sorghum Flour Standard OAS/Isotope and Wheat Flour Standard OAS/Isotope (Elemental Microanalysis, UK) for nitrogen and carbon isotope ratio (with, respectively, $\delta^{15} \mathrm{~N}$ air (Sorghum Flour OAS) $=1.58 \pm 0.15 \%$ o, $\delta^{15} \mathrm{~N}$ air(Wheat Flour OAS) $=$ $2.85 \pm 0.17 \%$ o, $\delta^{13} \mathrm{C}$ VPDB (Sorghum Flour OAS) $=-13.68 \pm 0.19 \%$ o, $\delta^{13} \mathrm{C}$ VPDB(Wheat Flour OAS) $=$ $-27.21 \pm 0.13 \%$ o), regularly checked against certified reference materials. Uncertainty of the isotope ratio analysis, calculated using values from six to nine replicates of secondary isotopic reference material interspersed among samples in every batch analysis, was $\leq 0.1 \%$. The major mass signals of $\mathrm{N}$ and $\mathrm{C}$ were used to calculate total $\mathrm{N}$ and $\mathrm{C}$ abundances, using Sorghum and Wheat Flour Standard OAS (Elemental Microanalysis, UK, with $1.47 \%$ N, $46.26 \%$ C and $1.47 \%$ N, 39.53\% C respectively) as elemental composition reference materials.

All the analyses were performed at the Stable Isotopes and Instrumental Analysis Facility (SIIAF), Faculty of Sciences of the University of Lisbon, Portugal.

\subsection{Isolation and Phenotypic Characterization of Nodule Bacteria}

For bacterial isolation, nodules were rehydrated in water during $12 \mathrm{~h}$ and surface-disinfected in $70 \% \mathrm{EtOH}$ for $1 \mathrm{~min}$, then transferred to commercial bleach for $6 \mathrm{~min}$ and $1 \mathrm{~min}$ in $70 \% \mathrm{EtOH}$, followed by six washes in sterile distilled water (adapted from Vincent [29]). For disinfection control, nodules were dried with sterile filter paper and rolled (surface printing) in YMA (Yeast Mannitol Agar) plates, incubated at $28^{\circ} \mathrm{C}$ for four days. YMA was chosen, once it is selective to nitrogen-fixers, allowing pre-selection when isolation. Only in the absence of growth the nodules were processed, preventing the growth of microorganisms from the soil or nodule surface.

Pools of $1-4$ nodules were crushed in $500 \mu \mathrm{L}$ of $0.85 \%$ sodium chloride; by serial dilutions method $\left(10^{0}\right.$ to $\left.10^{-3}\right)$, each suspension was inoculated in YMA supplemented with $0.01 \%$ cycloheximide and incubated for 12 days. Pure cultures were obtained after three or more subculturing steps using standard protocols [30] (p. 16), [31].

Macroscopic appearance of bacterial growth was analysed, through patterns of growth described for nutrient agar plates (days of growth, size, pigmentation, form, margin, and elevation), according to Cappuccino and Sherman [30]. Routine tests, namely Gram staining and potassium hydroxide $(\mathrm{KOH})$ test, catalase test and oxidase test were performed to cluster the colonies according to the results. Each of these tests has a dichotomic response, positive (+) or negative (-). All these tests were performed after $24 \mathrm{~h}$ of visible colonies growth.

\subsection{DNA Fingerprinting of Bacterial Isolates}

Genomic DNA was extracted using GES (Guanidium thiocyanate, Ethylenediamine tetraacetic acid (EDTA) and Sarkosyl) modified protocol [32]. One loop of colonies from each isolate was used. For mucous colonies, five washes in sterile water were performed through suspension in $1 \mathrm{~mL}$ of autoclaved water before lysis. The protocol was then followed, and DNA was resuspended in $100 \mu \mathrm{L}$ of $1 \times$ TE (Tris-EDTA).

Polymerase chain reaction (PCR )amplification for molecular fingerprinting was performed on a final volume of $25 \mu \mathrm{L}$, containing 50 ng of template DNA, $1 \mathrm{U}$ of Taq DNA polymerase (Invitrogen), 25 pmol of the primer csM13 (5' GAGGGTGGCGGTTCT 3'; [33]), $3 \mathrm{mM}$ of $\mathrm{MgCl}_{2}, 0.2 \mathrm{mM}$ of each dNTPs and $1 \times$ PCR buffer. The PCR temperature profiles were $5 \mathrm{~min}$ followed by 40 cycles of $95^{\circ} \mathrm{C}$ for $1 \mathrm{~min}, 50{ }^{\circ} \mathrm{C}$ for $2 \mathrm{~min}, 72{ }^{\circ} \mathrm{C}$ for $2 \mathrm{~min}$ and a final extension at $72{ }^{\circ} \mathrm{C}$ for $5 \mathrm{~min}$. Amplification products were resolved through electrophoresis on $1 \%(w / v)$ molecular biology agarose gel dissolved in $0.5 \times$ TBE buffer. Gels ran at $85 \mathrm{~V}$ for $5 \mathrm{~h}$. After running, they were stained in $0.5 \mu \mathrm{g} \cdot \mathrm{mL}^{-1}$ ethidium 
bromide for $10 \mathrm{~min}$, washed in water to remove excess staining and visualized under UV light in a transilluminator with the software Alliance 4.7 (Uvitec, Cambridge).

M13-PCR fingerprinting profiles were compared using BioNumerics software (Applied Maths, Sint-Martens-Latern, Belgium) and a dendrogram was performed using the Pearson correlation coefficient as association measure and the unweighted pair-group method with arithmetic mean (UPGMA) as clustering algorithm. Through this analysis, it was possible to cluster similar isolates, reducing our sample size, facilitating the selection to identification. An inherent limitation is ascribed to culture-dependent methods, which restricts our diversity analysis to cultivable microorganisms.

Reproducibility was analysed based on a random sample of $10 \%$ replicates of the total isolates, in order to establish the cut-off level. This represents the maximum level of similarity between two isolates to support their difference.

Shannon-Wiener and Simpson diversity indexes and Pielou evenness index [34] were used to calculate the diversity and evenness of the bacterial isolates of unburnt and burnt zones. A global approach was performed through cluster analysis, considering all the isolates obtained from unburnt zone and all from burnt zones. Indexes were then compared for further analysis.

\subsection{Identification of Bacterial Isolates by $16 S$ rRNA Gene Sequencing}

After discriminating isolates by DNA fingerprinting, the $16 \mathrm{~S}$ rRNA gene was amplified for a sub-set of isolates representative of almost all clusters, using two different primers combinations: PA(8f) with 907r or 104f with 1392r based on the Escherichia coli numbering system [35], depending on the success of amplification. SurfTaq (StabVida, Portugal) was the DNA polymerase used. The final volume of the PCR reaction was $20 \mu \mathrm{L}$, and the same master mix reagent concentration and temperature profiles were used, as previously described.

Following confirmation of a unique amplicon with the correct size, PCR products were purified using ExoSAP-IT ${ }^{\mathrm{TM}}$ PCR Product Cleanup Reagent (Thermo Fisher Scientific), according to the manufacturer's protocol. After purification, the samples were sequenced through Sanger sequencing (StabVida, Portugal).

DNA sequences were analysed with the software Geneious [36], performing alignments among each other and later with data available from GenBank through BLAST. Each sequence was considered individually and aligned with sequences available in the GenBank. The alignments with high similarity were considered and taxonomic identification was achieved according to maximum pairwise identity. Through this identification, it was possible to putatively identify other non-sequenced isolates by comparing similarities through dendrogram analysis. Sequences were submitted to GenBank with accession numbers MT465339 to MT465388 (Supplementary Table S1).

\subsection{Statistical Analysis}

Principal component analysis (PCA) was performed with normalized values of the number of nodules, the soil properties and isotopic analysis, by subtracting the mean of each variable to each value and dividing by the standard deviation. This approach was used to explore differences between the 6 sampled zones in order to identify the main discriminatory variables. Mean number of nodules collected in all unburnt and burnt zones were analysed by $t$-test at a $95 \%$ confidence level $(\alpha=0.05)$, as well as soil and isotopic data. All data collected were statistically analysed using packages FactoMiner and stats in R studio (v.3.6.1).

\section{Results}

\subsection{Nodulation of Young Plants}

In this study, 242 nodules were collected from unburnt zones and 337 nodules from burnt zones, for a total of 579 nodules. However, some variability was present in young acacias growing in sampled areas from both fire conditions. In unburnt zones 1, 2 and 3, 83, 128 and 31 nodules were counted, 
respectively, while in burnt zones 1, 2 and 3 these values were 168, 95 and 74, respectively. Although no relevant differences in size and morphologies were detected between nodules from zones with and without fire (data not shown), a higher and more diverse nodulation index was found in burnt zones, with an average number of 14.0 nodules per young plant, against 10.1 nodules per young plant in unburnt zones. The differences found between treatments, however, were not statistically significant $(p>0.05)$.

\subsection{Isotopic Analysis}

Nitrogen fixation efficiency in leaves was analysed through $\delta^{15} \mathrm{~N}$, revealing values close to $0 \%$ in both zones, in accordance with the occurrence of atmospheric nitrogen fixation through symbiosis. Despite no statistically significant differences between fire treatments, the values $-1.0 \%$ o for unburnt and $0.8 \%$ o for burnt ones were obtained from leaves, suggesting a higher nitrogen fixation in acacias growing in unburnt zones. In the nodules, no differences were found in $\delta^{15} \mathrm{~N}$ values from unburnt and burnt zones (7.9\%o and 7.4\%o respectively). $\delta^{15} \mathrm{~N}$ in the nodules remained extremely enriched (very positive values). Regarding $\delta^{13} \mathrm{C}$, there were no major differences between plants growing after fire conditions, both in leaves ( -30.2 for unburnt and -29.5 for burnt zones) and nodules ( -29.5 for unburnt and -28.8 for burnt zones) (see Table 2).

Table 2. Nitrogen and Carbon isotopic composition from leaves and nodules of $A$. longifolia young plants from unburnt (UBZ) and burnt (BZ) zones. The $\mathrm{N}$ and $\mathrm{C}$ isotopic compositions, $\delta^{15} \mathrm{~N}$ and $\delta^{13} \mathrm{C}$, respectively, and the percentage of these elements in leaves and nodules by $\% \mathrm{~N}$ and $\% \mathrm{C}$, as well as the ratio $\mathrm{C} / \mathrm{N}$ are also shown. Differences were not statistically significant, according to $t$-test with an $\alpha=0.05$.

\begin{tabular}{ccccccccccc}
\hline & \multicolumn{1}{c}{ Leaves } \\
\cline { 2 - 12 } & $\boldsymbol{\delta}^{\mathbf{1 5}} \mathbf{N}$ & $\boldsymbol{\delta}^{\mathbf{1 3}} \mathbf{C}$ & $\mathbf{\% N}$ & $\boldsymbol{\%} \mathbf{C}$ & $\mathbf{C} / \mathbf{N}$ & $\boldsymbol{\delta}^{\mathbf{1 5}} \mathbf{N}$ & $\boldsymbol{\delta}^{\mathbf{1 3}} \mathbf{C}$ & $\boldsymbol{\%} \mathbf{N}$ & $\boldsymbol{\%} \mathbf{C}$ & $\mathbf{C} / \mathbf{N}$ \\
\hline UBZ & -1.0 & -30.2 & 2.4 & 44.3 & 19.1 & 7.9 & -29.5 & 5.3 & 36.5 & 7.0 \\
\hline BZ & 0.8 & -29.5 & 3.3 & 43.5 & 15.2 & 7.4 & -28.8 & 6.3 & 42.3 & 7.0 \\
\hline
\end{tabular}

PCA Analysis

PCA biplots showed that three main components explained $76.9 \%$ of the variance. The unburnt and burnt zones are clearly separated in PC_1 (Dim1). This Dim1 explained 32.6\% of the total variance, mainly due to differences in $\delta^{15} \mathrm{~N} \_\mathrm{L}, \mathrm{P}_{2} \mathrm{O}_{5}, \mathrm{~K}_{2} \mathrm{O}$ and $\mathrm{N}-\mathrm{NO}_{3}$. PC_2 (Dim2) explained $25.6 \%$ of the variance, considering the $\mathrm{OM}$, total_N and $\mathrm{N}_{-} \mathrm{NH}_{4}$, while PC_3 (Dim3) explained 18.7\% of the variance, mainly due to differences in the number of nodules. The bidimensional representation of both PC1_PC2 and PC1_PC3 (Figure 2a,b) reveals a clear separation between the burnt and unburnt zones in both biplots, given the differences in the variables $\mathrm{P}_{2} \mathrm{O}_{5}, \mathrm{~K}_{2} \mathrm{O}, \mathrm{N}-\mathrm{NO}_{3}, \mathrm{OM}$, total_N, N-NH${ }_{4}$ and $\delta^{15} \mathrm{~N} \_\mathrm{L}$. All the variables increased with fire, except $\delta^{15} \mathrm{~N}_{-} \mathrm{L}$, which was lower in plants growing without fire, revealing a potentially higher nitrogen fixation. The difference in the number of nodules, higher after fire occurrence, is particularly relevant for PC3 (Figure 2b).

\subsection{Bacterial Fingerprinting and Identification}

A total of 153 isolates were obtained, 94 from the unburnt zone and 59 from the burnt zone. After phenotypic analysis, genomic fingerprinting based on csM13 was performed and the results are presented in the dendrogram of the Supplementary Figure S1. This dendrogram showed that isolates obtained from UBZ and BZ were scattered, and there were no clustering grouped accessions according to fire treatment. The isolates were mainly grouped according to its genera, although some genera with more representatives (e.g., Bradyrhizobium sp.) were clustered in different groups. A total of 19 clusters were identified. Some of the isolates were clustered independently, forming a group with a unique representative. 
a)

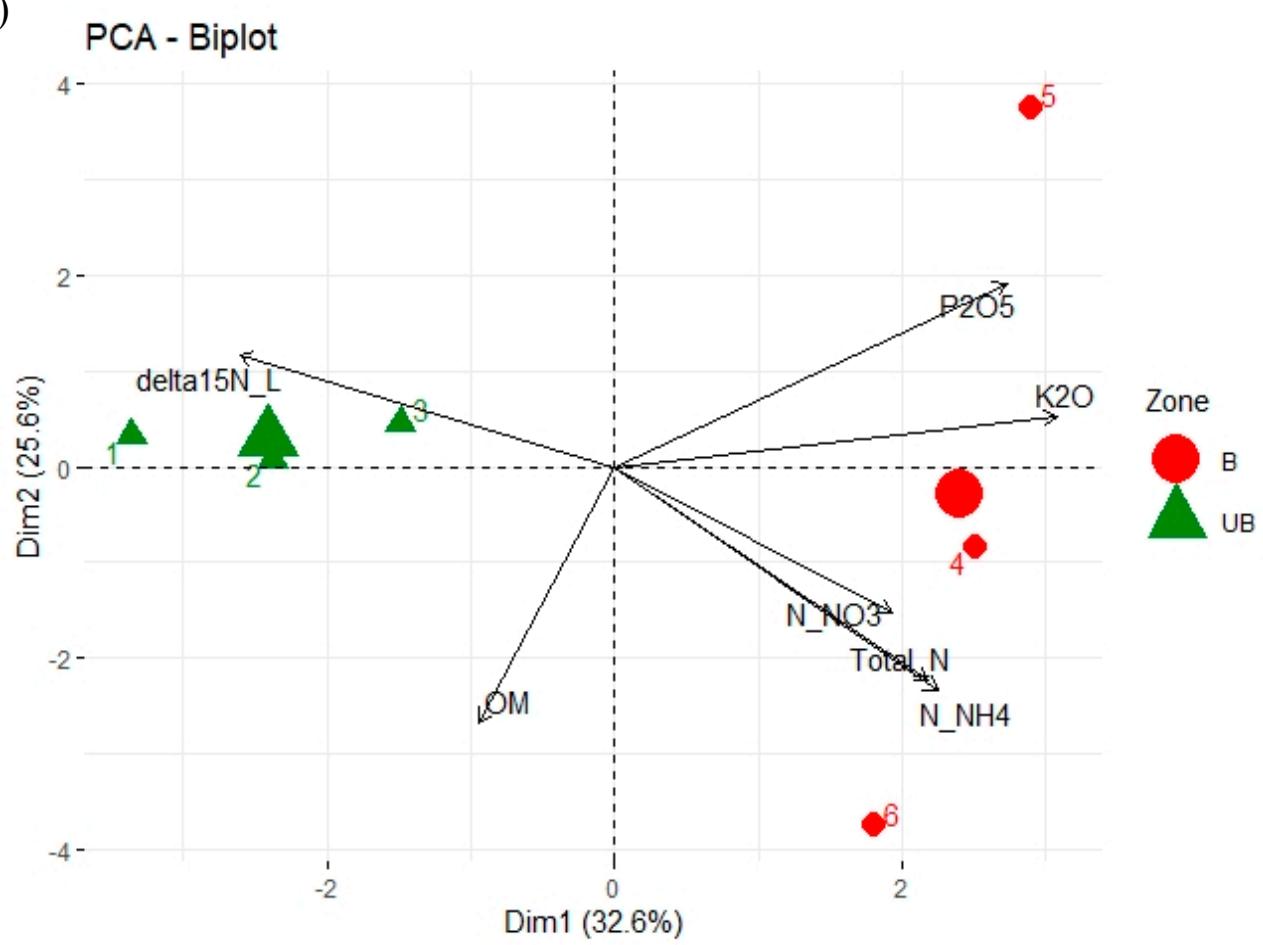

$\mathrm{b}$

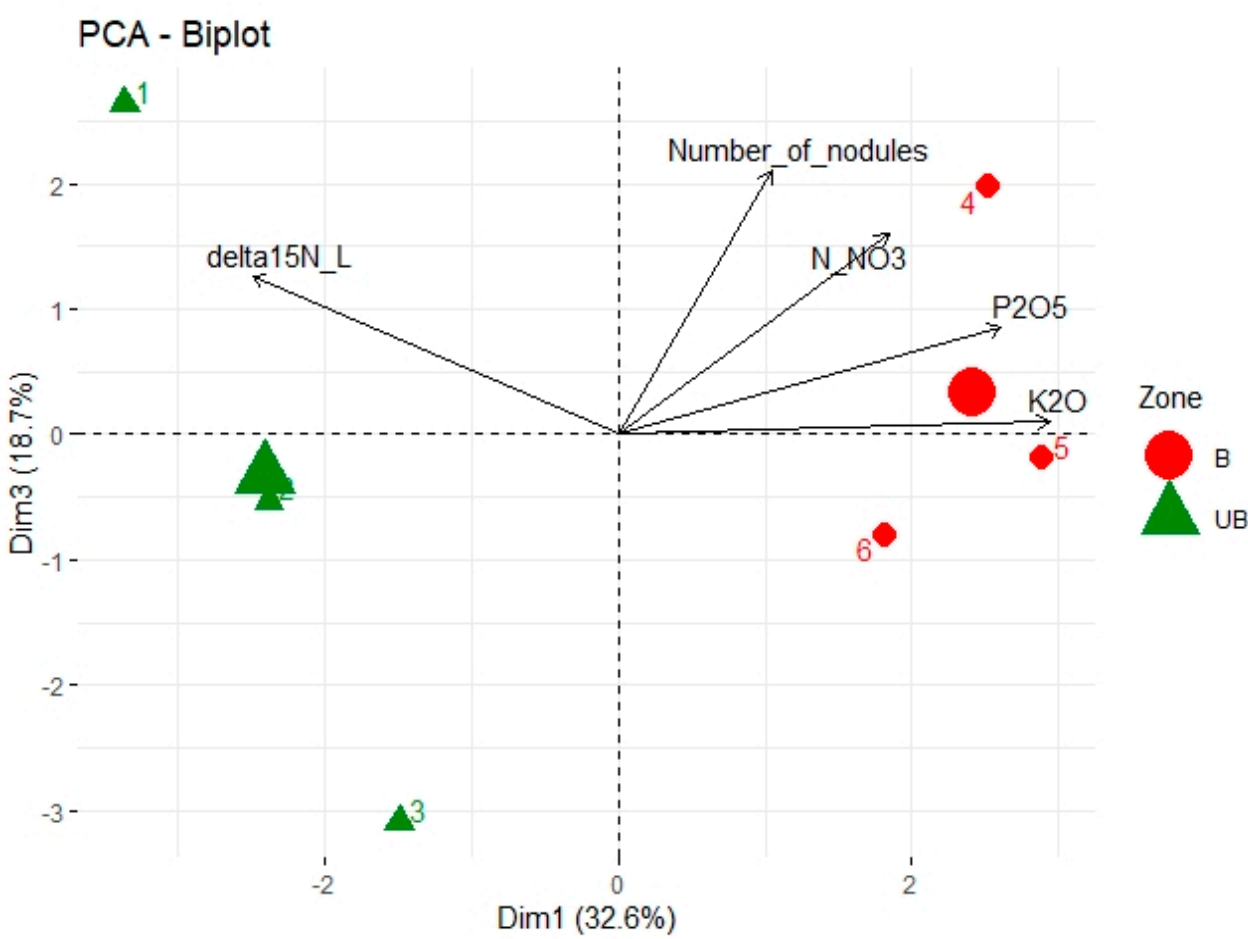

Figure 2. Principal Component Analysis (PCA) of soil properties and isotopic analysis from all unburnt (UBZ) and burnt zones (BZ), represented by Dim1 and Dim2 in (a) and Dim1 and Dim3 in (b). Only the main contributory variables to $\operatorname{Dim} 1$ and $\operatorname{Dim} 2$ are represented in $(\mathbf{a})$, which are $\delta^{15} \mathrm{~N} \_\mathrm{L}\left(\delta^{15} \mathrm{~N}\right.$ in leaves), $\mathrm{P} 2 \mathrm{O} 5$ (phosphorus), $\mathrm{K}_{2} \mathrm{O}$ (potassium oxide), $\mathrm{N}_{-} \mathrm{NO}_{3}$ (nitrates) for Dim1 and OM (organic matter), Total_N (total nitrogen) and $\mathrm{N} \_\mathrm{NH}_{4}$ (ammonia) for Dim2; only the main contributory variables to Dim1 and Dim3 are represented in $(\mathbf{b})$, which are the number of nodules for Dim3. Numbers 1, 2 and 3 represent the UBZ 1, UBZ 2 and UBZ 3 zones respectively, while 4,5 and 6 represent the BZ 1, BZ 2 and BZ 3 zones. 
$16 \mathrm{~S}$ rRNA gene sequencing allowed for the preliminarily identification of 50 isolates, with up to 94.2\% pairwise identity (See Supplementary Table S1). Bradyrhizobium and Paraburkholderia were the most represented genera with 23 and 10 isolates, respectively, followed by Pseudomonas, represented by seven isolates. Caballeronia, Duganella, Micrococcus, Moraxella, Paenibacillus, and Rhizobium were also identified genera (Supplementary Table S1). These data were considered together with the dendrogram analysis, allowing the inference of the identification of other isolates belonging to the same cluster, following a previous similarity evaluation of the fingerprinting profile. As a result, more genera are represented in UBZ comparing to BZ. Considering the 153 isolates obtained, the 94 isolates from unburnt zone were distributed in five different classes: Alphaproteobacteria (39.4\%), Betaproteobacteria $(26.6 \%)$ and Gammaproteobacteria (16\%) from phylum Proteobacteria; Actinobacteria (3.2\%) from phylum Actinobacteria and Bacilli (2.1\%) from phylum Firmicutes. Part of the collection remained unclassified, accounting for $12.8 \%$ of the isolates. The 59 isolates from burnt zone were distributed in four different classes: Alphaproteobacteria (45\%), Betaproteobacteria (13.3\%) and Gammaproteobacteria (10\%) from phylum Proteobacteria; Actinobacteria (8.3\%) from phylum Actinobacteria. Additionally, $23.3 \%$ of the isolates remained unclassified (Figure 3 and Table 3). A curious and unexpected result was the presence of only one cluster with three isolates identified as Rhizobium sp. and the absence of isolates from Sinorhizobium and Mesorhizobium genera. Regarding species identification, Bradyrhizobium cytisi is the most represented one (Supplementary Table S1). In fact, through the diversity and evenness indexes, we found a higher diversity in the unburnt zone and a dominance of a species, Bradyrhizobium cytisi, in both zones, as already mentioned. As shown by Shannon-Wiener diversity index, there was a higher diversity in isolates from the unburnt zone $\left(\mathrm{H}^{\prime}=1.0\right)$ than from the burnt zone $\left(\mathrm{H}^{\prime}=0.74\right)$. The Pielou evenness index revealed that in both zones some isolates were dominant $\left(\mathrm{J}^{\prime}=0.75\right.$ for unburnt zone and 0.67 for burnt zone). The Simpson diversity index also showed a high diversity for both the unburnt zone $\left(\mathrm{D}^{\prime}=0.97\right)$ and burnt zone $\left(\mathrm{D}^{\prime}=0.98\right)$.

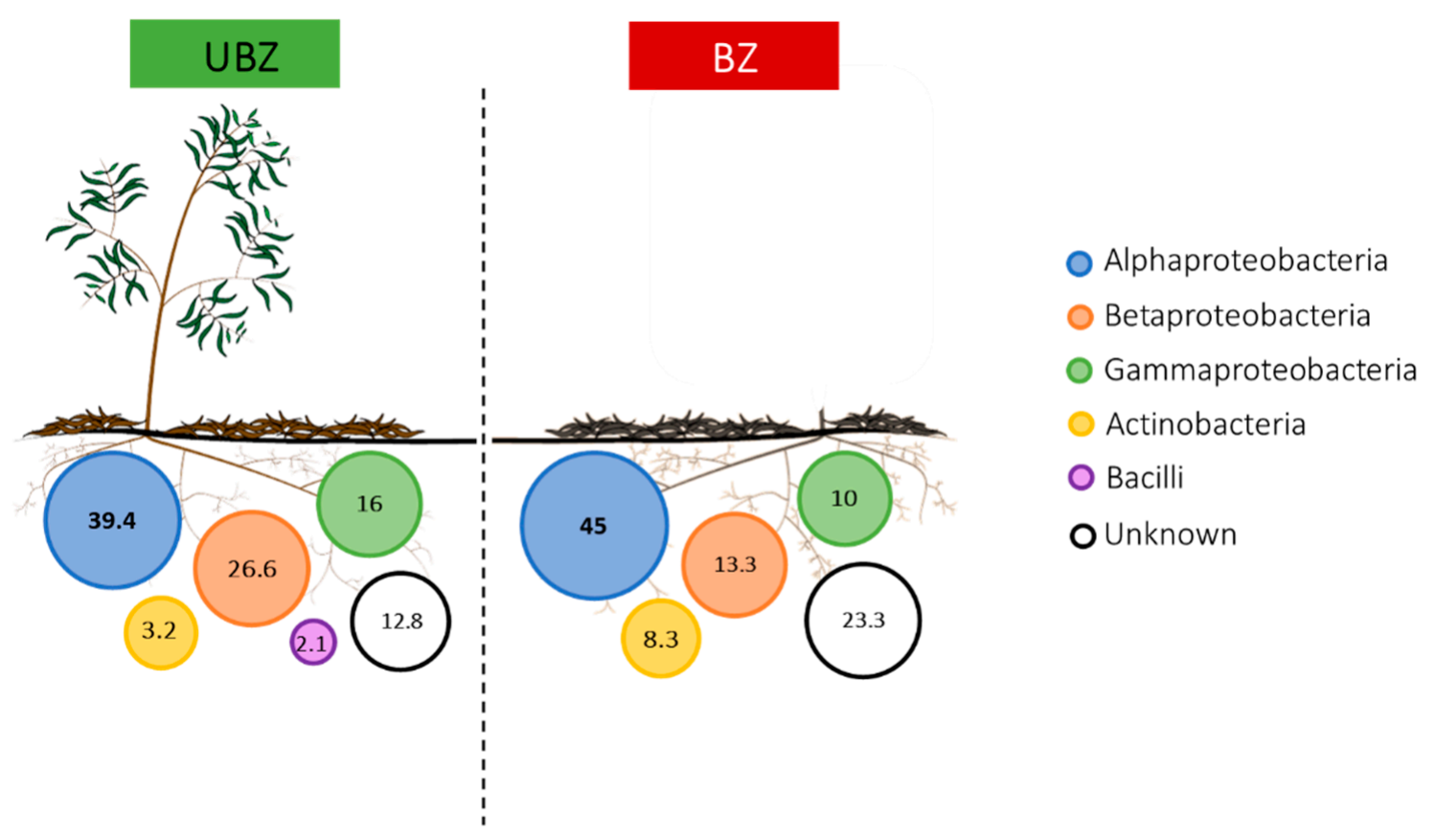

Figure 3. Percentage of the distribution of the different phyla/class of bacterial isolates from $A$. longifolia young plants nodules, present in both unburnt (UBZ) and burnt zones (BZ). 
Table 3. Total of isolates identified within each unburnt (UBZ 1, UBZ 2, UBZ3) and burnt (BZ 1, BZ 2, BZ 3) zone. Colours indicate the phylum of each genus (Proteobacteria/ $\alpha$-proteobacteria (blue), Proteobacteria/ $\beta$-proteobacteria (orange), Proteobacteria $/ \gamma$-proteobacteria (green), firmicutes/Bacilli (purple) and actinobacteria/Actinobacteria (yellow).

\begin{tabular}{ccccccc}
\hline Genera/Zones & UBZ 1 & UBZ 2 & UBZ 3 & BZ 1 & BZ 2 & BZ 3 \\
\hline Althererythrobacter sp. & 0 & 0 & 1 & 0 & 0 & 0 \\
\hline Bradyrhizobium sp. & 9 & 12 & 13 & 6 & 16 & 5 \\
\hline Paracoccus sp. & 0 & 1 & 0 & 0 & 0 & 0 \\
\hline Rhizobium sp. & 0 & 1 & 0 & 0 & 0 & 0 \\
\hline Caballeronia sp. & 2 & 0 & 0 & 1 & 0 & 0 \\
\hline Duganella sp. & 8 & 0 & 0 & 0 & 0 & 0 \\
\hline Paraburkholderia sp. & 4 & 6 & 5 & 4 & 2 & 1 \\
\hline Moraxella sp. & 2 & 0 & 0 & 1 & 1 & 2 \\
\hline Pseudomonas sp. & 12 & 0 & 1 & 1 & 4 & 1 \\
\hline Micrococcus sp. & 2 & 0 & 0 & 1 & 1 & 2 \\
\hline Nocardioides sp. & 1 & 0 & 0 & 1 & 0 & 0 \\
\hline Paenibacillus sp. & 0 & 0 & 2 & 0 & 0 & 0 \\
\hline Unknown & 1 & 10 & 1 & 9 & 3 & 2 \\
\hline Total & 41 & 30 & 23 & 23 & 26 & 10 \\
\hline
\end{tabular}

\section{Discussion}

\subsection{Nodulation: Does Fire Play a Role?}

After fire, soils are enriched in ammonia and nitrates, as expected considering they are the inorganic forms of nitrogen produced [37], which is shown by values of $\mathrm{N}_{-} \mathrm{NH}_{4}{ }^{+}$and $\mathrm{N}_{-} \mathrm{NO}_{3}{ }^{-}$(mineral $\mathrm{N}$ forms) that almost doubled for burnt soils (see Table 1). Previous studies proposed that nodulation is downregulated through environmental feedback within the presence of ammonia, ultimately saving resources [38,39]. Additionally, Streeter [40] and Gordon et al. [41] showed that the presence of nitrates on the soil could delay nodule development. Notwithstanding, in the present study, nodulation seems to be potentiated somehow after the fire, as observed by the higher average number of nodules found in young plants growing in burnt study sites. Interestingly, through PCA biplot analysis, it can be seen that the isotopic signature of nitrogen in leaves, represented by $\delta^{15} N_{-} L$ suggests that nitrogen fixation in post-fire conditions is not correlated with the number of nodules (Figure 2b). Even considering the lower number of nodules in unburnt zones, an increased symbiotic nitrogen fixation occurred. On the other hand, there is a negative correlation between $\delta^{15} \mathrm{~N}$ in leaves and mineral $\mathrm{N}$ forms, pointing out symbiotic nitrogen fixation dependency in the absence of mineral $\mathrm{N}$ forms, as it is occurring in unburnt zones (Figure 2a). With this in mind, why does A. longifolia invest in nodulation? We may hypothesize that these young plants may respond to fire events, showing a different behaviour in this "new" environment, which may be particularly relevant for plant fitness. Additionally, studies developed by Harper [42], showed that a supply of both soil and symbiotic nitrogen is required for a more favourable production of soybean. For this reason, we can possibly extend this hypothesis of partial contribution of both soil and symbiotic nitrogen to A. longifolia too, especially in the after-fire scenario that requires a faster adaptation.

Interestingly, $\delta^{15} \mathrm{~N}$ in nodules is extremely enriched in both zones, indicating absence of atmospheric nitrogen fixation. One potential explanation could be ascribed to a fractionation leading to an enrichment associated with nodule development and compounds' synthesis to export, with the second one contributing more [43]. Moreover, and in the same direction of an additional fractionation towards a higher enrichment in nodule tissue, Michelsen et al. [44] showed that ${ }^{15} \mathrm{~N}$ abundance could be influenced by the presence of mycorrhizal fungi, leading to an enriched value of the host plant up to $8 \%$. Considering this, we can hypothesize that $\delta^{15} \mathrm{~N}$ signature and the respective ${ }^{15} \mathrm{~N}$ enrichment in collected nodules could be due to an association with fungi, along with bacteria presence, which was not explored in the present study. Further studies should focus on exploring this possibility of tripartite 
symbiosis already described for other Acacia species [45], along with nitrogen compounds exported to the plant.

The nodulation process involves the acquisition of symbiotic partners engaged in nitrogen fixation that consequently allows A. longifolia to access a different pool of nitrogen, facilitating recolonization. For this reason, nodulation seems to be a good process to allocate energy in, leading to its successful dominance. The higher quantity of $\mathrm{P}_{2} \mathrm{O}_{5}$ present in burnt soils (five times higher compared with unburnt soils, Table 1), is also an important factor to consider and previous studies have related it with nodules development, quantity, and function [46,47]. In the present study, we can consider it a facilitator for nodule formation in burnt zones in comparison to unburnt, due to a possible limitation in the second.

PCA biplots show a clear separation between unburnt and burnt zones, but besides this natural variability among three unburnt and three burnt zones, there is a tendency for a similar response due to ecosystem rebalance capacity after a disturbance, like a fire.

\subsection{Nodule Bacteriome: Who Is Taking Part?}

A. longifolia seems to establish symbiosis with different bacteria, beyond the commonly described rhizobia and, for the first time, our study was focused on studying bacteriome diversity in this plant species beyond nitrogen-fixers. Its "bacteriome" seems to include $\alpha$-Proteobacteria, $\beta$-Proteobacteria, $\gamma$-Proteobacteria, Firmicutes and Actinobacteria. Thus, we can hypothesize that within an invasive range, A. longifolia can take advantage of its promiscuity, outcompeting native species, and investing energy in nodulation, considering that its ability to obtain symbiotic partners is facilitated. Furthermore, A. longifolia could be an example of Taylor et al.'s [48] studies who suggested that legumes, as individuals, could establish symbiosis with multiple rhizobia species simultaneously, again a direct consequence of promiscuity, making A. longifolia a generalist mutualist. Besides this, several studies [19,49-51] showed that Bradyrhizobium is the most common symbiont genus in both native and invasive range of Acacia species, A. longifolia included, which is confirmed in our study both by dominance and intrageneric diversity. Bradyrhizobium cytisi is the main partner among this genus and it is described here for the first time as being involved in symbiosis with A. longifolia. On the other hand, B. japonicum, previously described as the major partner by Rodríguez-Echeverría [23], in both native and non-native ranges [52], was not present among our isolates. Besides other Bradyrhizobium species including isolates only identified to genus level, B. canariense, B. ganzhouense/B. rifense and B. pachyrhizi were also present highlighting the intrageneric diversity and genus dominance, which is in accordance with Rodríguez-Echeverría [18], who already mentions B. ganzhouense as present in Acacia nodules.

Surprisingly, we only observe three isolates belonging to Rhizobium genus, namely Rhizobium rhizogenes at species level (Supplementary Figure S1, Supplementary Table S1), which was a genus already described as one of the main symbionts among legumes [53], and particularly among Acacia genus in Australia (native range) [49,54]; In our study, i.e., within an invasive range, it was not so dominant. Rhizobia obtained from nodules, isolated in nitrogen-free medium as performed in our work, has been described as functional in nitrogen fixation in Leguminosae by several authors $[55,56]$. These authors showed that Sinorhizobium and/or Mesorhizobium related strains, isolated from Medicago and Acacia, were highly effective in nitrogen fixation (as assessed by its $\mathrm{N}_{2}$ fixation effectiveness index) and induction of nodulation.

Paraburkholderia and Pseudomonas were two genera also present in our collection. Paraburkholderia caledonica and Pseudomonas moorei were already described as plant growth promoting bacteria (PGPB), playing the role of nodule inducers, presenting similarities to rhizobial species, regarding nif genes and nod factors [57]. Additionally, Saïdi et al. [58] showed that Pseudomonas spp. could have a role as P-solubilizer and in siderophore production. Furthermore, Martínez-Hidalgo and Hirsch [26], in their review, also highlighted the role of Micrococcus strains, a genus to which some isolates in our collection belong, as a plant-development "helper". With this in mind, the question that remains is what could be the role of these non-fixing bacteria in A. longifolia nodulation? 
In this context, recent studies postulate that the more diverse a bacterial community is within a symbiosis, the more likely it contains an effective symbiont. Such diverse symbiotic partnerships were explained by Mårtensson et al. [59] that showed that legumes cannot predict the nitrogen fixation efficiency before nodules are established and fixation is in progress; if so, we may hypothesize that A. longifolia emits signals that can be received by several soil bacteria. Other authors [60] have proposed that legumes can control nodulation through oxygenation of nodule microenvironment, leading to bacteria death and nodule senescence, showing that "the host controls the party" [61]. Considering this, diversity is easy to be under control. This could be A. longifolia's strategy, supported by Bradyrhizobium spp. dominance and diversity. We can hypothesize that a process of specialization is present between A. longifolia and Bradyrhizobium spp., by comparison of unburnt and burnt zones. Thus, this symbiotic partner ensures efficient nitrogen fixation, as an obligatory partner. This great representation of Bradyrhizobium spp. can occur considering that different strains of the same rhizobia may differ in their effectiveness [62].

It is also known that some bacteria have functional traits that could complement each other in a way to facilitate a third functional trait [63], which is also potentiated within a wide-range community, with Paraburkholderia spp., Pseudomonas spp. and Micrococcus spp. presence, as possibly occurred in the present study. For this reason, further investigation should rely on the functions that could be performed by bacteria hosted in nodules, along with nitrogen fixation. In other words, nodulation would be much more than just a way to get ammonia. An interesting comparison could be carried out using Next Generation Sequencing techniques to assess a much greater diversity present inside nodules and that will complement this culture-dependent approach.

While Richardson et al. [64] suggested that mutualisms render plant species less prone to invade, our study shows that $A$. longifolia symbiosis seems to contribute for plant growth and colonization that can be due to an unspecific plant-bacteria interaction already mentioned. In fact, one of the main reasons why $A$. longifolia is such an aggressive invader, described as ecosystem-engineer, is its capacity to be eventually infected and establish relationships with a wide-range diversity of bacteria available in soils. In addition, belowground microbial diversity is substantially different after fires and this non-specific partnership can as such be useful. Besides the higher diversity in unburnt zones, some selection seems to occur in burnt zones. As reported by Franche et al. [65], diversity found within nodules' "bacteriome" is exclusively between nif genes carrying bacteria and/or already described nitrogen-fixers. This specialization is also according to the nitrogen fixation pathways corroborated by the $\delta^{15} \mathrm{~N}$ in leaves ascribed to atmospheric nitrogen fixation through symbiosis (Table 2).

\subsection{Bacteriome: What Could be Occurring?}

As a costly process, nodulation has implicit a complex signal exchange, with the plant responsible for attracting bacteria possessing nif genes to fix nitrogen [61]. This is, as far as we know, the main goal of nodulation. This nodule "bacteriome" diversity can be explained by the inherent highly functional- and taxonomically diverse soil microbiome, along with an absence of restriction on entry into A. longifolia root system. Of equal importance is the process of horizontal gene transfer (HGT) that can be a determinant mechanism to facilitate this entry. In short, genes involved in signal exchange and nodulation are part of symbiotic plasmids or highly mobile "symbiotic islands", which can be transferred easily between different bacterial species, and even genera [66]. For this reason, "bacteriome" diversity could lead more easily to effective nodulation, once beneficial bacteria can take part in nodulation, allowing A. longifolia to grow and spread, faster than other species, underlining the absence of competition after fires. Of course, among potential efficient nitrogen-fixers, some hitchhikers could take a ride and take advantage of nodule environment, stressing why bacteriome functionality should be explored.

Plant-bacteria interactions might, in fact, be highly regulated by environment. The observed highly efficient bacterial community inside nodules makes A. longifolia a top invasive species. Future studies should rely on nodule functionality, activity, and regulation, once which host "controls" the party is 
known, with guests having their own behaviour. The extent of this approach to native range could be a great contribution to understanding the invasive behaviour of $A$. longifolia and ultimately leading to its control.

\section{Conclusions}

In the present study, fire influenced bacterial diversity inside nodules, maintaining its nitrogen fixation functionality. After the fire disturbance, A. longifolia apparently "selects" nitrogen-fixing bacteria, culminating in Bradyrhizobium spp. dominance and intrageneric diversity. B. cytisi and other species in this genus seem to have a determinant role in symbiosis with A. longifolia, revealing a close relation and a putative facilitation role. However, besides this straight relation with A. longifolia-Bradyrhizobium spp., a considerable bacterial diversity was reported in our study, that could be functionally diverse and render nodules a highly complex structure.

A. longifolia is a typical invader that easily adapts to disturbances, and environmental changes seem to cause a different response in unburnt and burnt zones. This highlights the mutual contribution of ammonia/nitrates and symbiotic nitrogen fixation to plant development, albeit with fast ecosystem rebalance capacity.

Thus, regarding its major impacts, A. longifolia is not only an "ecosystem-engineer" in the aboveground environment, but also, due to its efficiency in selecting bacterial guests, it behaves as an "engineer" of the belowground environment, too.

Supplementary Materials: The following are available online at http://www.mdpi.com/1424-2818/12/6/250/s1. Figure S1: Dendrogram based on cluster analysis of fingerprinting PCR profiles of the isolates from A. longifolia nodules, using the Pearson correlation coefficient and the unweighted pair-group method with arithmetic mean algorithm (UPGMA). 84\% was the cut-off level below which isolates could be considered different. On the right are represented: isolate identification (CJJ xxx), zone from where it was isolated (UBZ/BZ $x)$, Gram test result, morphology (rods (B) or cocci (CC)), catalase test result and oxidase test result, both $(+)$ or $(-)$. Colours are according to the phylum/class into each genus belong to: Proteobacteria/ $\alpha$-proteobacteria (blue), Proteobacteria/ $\beta$-proteobacteria (orange), Proteobacteria/ $\gamma$-proteobacteria (green), firmicutes/Bacilli (purple) and actinobacteria/Actinobacteria (yellow). Roman numbering identifies clusters. Isolates are identified up to genus level, Table S1: Identification of bacterial isolates obtained from unburnt and burnt zones by BLAST analysis of the $16 \mathrm{~S}$ rRNA gene sequences. GenBank accession numbers are also indicated.

Author Contributions: J.G.d.J. did the data collection. J.G.d.J. and H.T. outlined the original draft. All authors contribute to the conceptualization, methodology, data analysis and interpretation, as well as the review and edition of the manuscript. All authors have read and agreed to the published version of the manuscript.

Funding: This research was funded by FCT/MCTES, with the financial support of CESAM UIDP/50017/2020 + UIDB/50017/2020, FCT and BioISI, Research Unit grant number UIDB/04046/2020 and FCT and cE3c, Research Unit grant number UIDB/00329/2020 and also R3forest-PCIF/GVB/0202/2017.

Acknowledgments: We thank Rodrigo Maia for the helpful support with isotopic analysis. We are grateful to Andreia Anjos for all the help in the field work.

Conflicts of Interest: The authors declare no conflicts of interest.

\section{References}

1. Davis, M.A.; Chew, M.K.; Hobbs, R.J.; Lugo, A.E.; Ewel, J.J.; Vermeij, G.J.; Brown, J.H.; Rosenzweig, M.L.; Gardener, M.R.; Carroll, S.P.; et al. Don't judge species on their origins. Nature 2011, 474, 153-154. [CrossRef] [PubMed]

2. Hierro, J.L.; Maron, J.L.; Callaway, R.M. A biogeographical approach to plant invasions: The importance of studying exotics in their introduced and native range. J. Ecol. 2005, 93, 5-15. [CrossRef]

3. Richardson, D.M.; Pyšek, P. Plant Invasions. Encycl. Biodivers. 2013, 6, 90-102. [CrossRef]

4. Foyer, C.H.; Lam, H.M.; Nguyen, H.T.; Siddique, K.H.; Varshney, R.K.; Colmer, T.D.; Cowling, W.; Bramley, H.; Mori, T.A.; Hodgson, J.M.; et al. Neglecting legumes has com- promised human health and sustainable food production. Nat. Plants 2016, 2, 16112. [CrossRef]

5. Maslin, B.R.; Miller, J.; Seigler, D.S. Overview of the generic status of Acacia (Leguminosae: Mimosoideae). Aust. Syst. Bot. 2003, 16, 1-18. [CrossRef]

6. Whibley, D.J.E. Acacias of South Australia; Wollman, D.J., Ed.; Government Printer: Adelaide, Australia, 1980. 
7. Alonso, P.S.; Rodríguez, J.; González, L.; Lorenzo, P. Here to stay. Recent advances and perspectives about Acacia invasion in Mediterranean areas. Ann. For. Sci. 2017, 74, 55. [CrossRef]

8. Peperkorn, R.; Werner, C.; Beyschlag, W. Phenotypic plasticity of an invasive acacia versus two native Mediterranean species. Funct. Plant Biol. 2005, 32, 933-944. [CrossRef]

9. Morais, M.C.; Marchante, H.; Marchante, H. Big troubles are already here: Risk assessment protocol shows high risk of many alien plants present in Portugal. J. Nat. Conserv. 2017, 35, 1-12. [CrossRef]

10. Stock, W.D.; Wienand, K.T.; Baker, A.C. Impacts of invading N2-fixing Acacia species on patterns of nutrient cycling in two Cape ecosystems: Evidence from soil incubation studies and $15 \mathrm{~N}$ natural abundance values. Oecologia 1995, 101, 375-382. [CrossRef]

11. Marchante, H.; Marchante, E.; Buscardo, E.; Maia, J.; Freitas, H. Recovery Potential of Dune Ecosystems Invaded by an Exotic Acacia Species (Acacia longifolia)1. Weed Technol. 2004, 18, 1427-1433. [CrossRef]

12. Yelenik, S.G.; Stock, W.D.; Richardson, D.M. Functional Group Identity Does not Predict Invader Impacts: Differential Effects of Nitrogen-fixing Exotic Plants on Ecosystem Function. Biol. Invasions 2006, 9, 117-125. [CrossRef]

13. Carvalho, L.; Antunes, P.M.; Martins-Loução, M.A.; Klironomos, J.N. Disturbance influences the outcome of plant-soil biota interactions in the invasive Acacia longifolia and in native species. Oikos 2010, 119, 1172-1180. [CrossRef]

14. Ulm, F.; Hellmann, C.; Cruz, C.; Máguas, C. N/P imbalance as a key driver for the invasion of oligothrophic dune systems by a woody legume. Oikos 2016, 126, 231-240. [CrossRef]

15. Meira-Neto, J.A.A.; Da Silva, M.C.N.A.; Tolentino, G.S.; Gastauer, M.; Buttschardt, T.; Ulm, F.; Máguas, C. Early Acacia invasion in a sandy ecosystem enables shading mediated by soil, leaf nitrogen and facilitation. Biol. Invasions 2017, 20, 1567-1575. [CrossRef]

16. Andrews, M.; Andrews, M. Specificity in Legume-Rhizobia Symbioses. Int. J. Mol. Sci. 2017, 18, 705. [CrossRef]

17. Kamutando, C.N.; Vikram, S.; Kamgan-Nkuekam, G.; Makhalanyane, T.P.; Greve, M.; Le Roux, J.J.; Richardson, D.M.; Cowan, D.A.; Valverde, A. The Functional Potential of the Rhizospheric Microbiome of an Invasive Tree Species, Acacia dealbata. Microb. Ecol. 2018, 77, 191-200. [CrossRef]

18. Rodríguez-Echeverría, S. Rhizobial hitchhikers from Down Under: Invasional meltdown in a plant-bacteria mutualism? J. Biogeogr. 2010, 37, 1611-1622. [CrossRef]

19. Lafay, B.; Burdon, J.J. Small-Subunit rRNA Genotyping of Rhizobia Nodulating Australian Acacia spp. Appl. Environ. Microbiol. 2001, 67, 396-402. [CrossRef]

20. Marsudi, N. Identification and characterization of fast- and slow-growing root nodule bacteria from South-Western Australian soils able to nodulate Acacia saligna. Soil Biol. Biochem. 1999, 31, 1229-1238. [CrossRef]

21. Nick, G.; De Lajudie, P.; Eardly, B.D.; Suomalainen, S.; Paulin, L.; Zhang, X.; Gillis, M.; Lindström, K. Sinorhizobium arboris sp. nov. and Sinorhizobium kostiense sp. nov., isolated from leguminous trees in Sudan and Kenya. Int. J. Syst. Evol. Microbiol. 1999, 49, 1359-1368. [CrossRef]

22. Nick, G.; Jussila, M.; Hoste, B.; Niemi, M.; Kaijalainen, S.; Lajudie, P.; de Gillis, M.; Bruijn, F.J.; de Lindström, K. Rhizobia isolated from root nodules of tropical leguminous trees characterized using DNA-DNA dot-blot hybridization and rep-PCR genomic fingerprinting. Syst. Appl. Microbiol. 1999, 22, 287-299. [CrossRef]

23. Rodríguez-Echeverría, S.; Crisostomo, J.; Freitas, H. Genetic Diversity of Rhizobia Associated with Acacia longifolia in Two Stages of Invasion of Coastal Sand Dunes. Appl. Environ. Microbiol. 2007, 73, 5066-5070. [CrossRef]

24. Rodríguez-Echeverría, S.; Le Roux, J.J.; Crisostomo, J.; Ndlovu, J. Jack-of-all-trades and master of many? How does associated rhizobial diversity influence the colonization success of Australian Acacia species? Divers. Distrib. 2011, 17, 946-957. [CrossRef]

25. Weiss, P.W. Seed characteristics and regeneration of some species in invaded coastal communities. Austral Ecol. 1984, 9, 99-106. [CrossRef]

26. Martínez-Hidalgo, P.; Hirsch, A.M. The Nodule Microbiome: N2-Fixing Rhizobia Do Not Live Alone. Phytobiomes J. 2017, 1, 70-82. [CrossRef]

27. Boletim climatológico 2018. Available online: http://www.ipma.pt/pt/publicacoes/boletins (accessed on 30 April 2020). 
28. Sankhla, I.S.; Tak, N.; Meghwal, R.R.; Choudhary, S.; Tak, A.; Rathi, S.; Sprent, J.I.; James, E.K.; Gehlot, H. Molecular characterization of nitrogen fixing microsymbionts from root nodules of Vachellia (Acacia) jacquemontii, a native legume from the Thar Desert of India. Plant Soil 2016, 410, 21-40. [CrossRef]

29. Callow, J.A.; Vincent, J.M. A Manual for the Practical Study of Root-Nodule Bacteria. J. Appl. Ecol. 1971, 8, 977. [CrossRef]

30. Cappuccino, J.; Sherman, N. Experiment 2, Techniques for Isolation of Pure Cultures. In Microbiology, A Laboratory Manual, 5th ed.; Benjamin-Cummings Pub Co: San Francisco, CA, 1998; p. 16.

31. Crisostomo, J.; Rodríguez-Echeverría, S.; Freitas, H. Co-introduction of exotic rhizobia to the rhizosphere of the invasive legume Acacia saligna, an intercontinental study. Appl. Soil Ecol. 2013, 64, 118-126. [CrossRef]

32. Pitcher, D.; Saunders, N.; Owen, R. Rapid extraction of bacterial genomic DNA with guanidium thiocyanate. Lett. Appl. Microbiol. 1989, 8, 151-156. [CrossRef]

33. Vassart, G.; Georges, M.; Monsieur, R.; Brocas, H.; Lequarre, A.; Christophe, D. A sequence in M13 phage detects hypervariable minisatellites in human and animal DNA. Science 1987, 235, 683-684. [CrossRef]

34. Krebs, C. Ecological Methodology; Harper Collins: New York, NY, USA, 1989.

35. Marchesi, J.R.; Sato, T.; Weightman, A.J.; Martin, T.A.; Fry, J.C.; Hiom, S.J.; Wade, W.G. Design and Evaluation of Useful Bacterium-Specific PCR Primers That Amplify Genes Coding for Bacterial $16 \mathrm{~S}$ rRNA. Appl. Environ. Microbiol. 1998, 64, 795-799. [CrossRef]

36. Geneious v5.3. 2010. Available online: http://www.geneious.com (accessed on 3 April 2019).

37. Covington, W.; Sackett, S. Soil mineral nitrogen changes following prescribed burning in ponderosa pine. For. Ecol. Manag. 1992, 54, 175-191. [CrossRef]

38. Lim, C.W.; Lee, Y.W.; Lee, S.C.; Hwang, C.H. Nitrate inhibits soybean nodulation by regulating expression of CLE genes. Plant Sci. 2014, 229, 1-9. [CrossRef]

39. Ferguson, B.; Foo, E.; Ross, J.J.; Reid, J. Relationship between gibberellin, ethylene and nodulation in Pisum sativum. New Phytol. 2010, 189, 829-842. [CrossRef]

40. Streeter, J.; Wong, P.P. Inhibition of legume nodule formation and N2fixation by nitrate. Crit. Rev. Plant Sci. 1988, 7, 1-23. [CrossRef]

41. Gordon, A.; Skot, L.; James, C.; Minchin, F.R. Short-term metabolic responses of soybean root nodules to nitrate. J. Exp. Bot. 2002, 53, 423-428. [CrossRef]

42. Harper, J.E. Soil and symbiotic nitrogen requirements for optimum production of soybean. Crop Sci. 1974, 14, 255-260. [CrossRef]

43. Shearer, G.; Bryan, B.A.; Kohl, D.H. Increase of Natural 15N Enrichment of Soybean Nodules with Mean Nodule Mass. Plant Physiol. 1984, 76, 743-746. [CrossRef]

44. Michelsen, A.; Quarmby, C.; Sleep, D.; Jonasson, S. Vascular plant $15 \mathrm{~N}$ natural abundance in heath and forest tundra ecosystems is closely correlated with presence and type of mycorrhizal fungi in roots. Oecologia 1998, 115, 406-418. [CrossRef]

45. Mortimer, P.E.; Le Roux, M.R.; Perez-Fernandez, M.; Benedito, V.A.; Kleinert, A.; Xu, J.-C.; Valentine, A. The dual symbiosis between arbuscular mycorrhiza and nitrogen fixing bacteria benefits the growth and nutrition of the woody invasive legume Acacia cyclops under nutrient limiting conditions. Plant Soil 2012, 366, 229-241. [CrossRef]

46. Israel, D.W. Investigation of the Role of Phosphorus in Symbiotic Dinitrogen Fixation. Plant Physiol. 1987, 84, 835-840. [CrossRef]

47. Jensen, H.H.; Schjoerring, J.K.; Soussana, J.-F. The Influence of Phosphorus Deficiency on Growth and Nitrogen Fixation of White Clover Plants. Ann. Bot. 2002, 90, 745-753. [CrossRef]

48. Taylor, B.; Simms, E.L.; La Pierre, K.J. More Than a Functional Group: Diversity within the Legume-Rhizobia Mutualism and Its Relationship with Ecosystem Function. Diversity 2020, 12, 50. [CrossRef]

49. Barnet, Y.; Catt, P.; Hearne, D. Biological Nitrogen Fixation and Root-Nodule Bacteria (Rhizobium Sp. and Bradyrhizobium Sp.) In Two Rehabilitating Sand Dune Areas Planted With Acacia Spp. Aust. J. Bot. 1985, 33, 595-610. [CrossRef]

50. Barnet, Y.; Catt, P. Distribution and characteristics of root-nodule bacteria isolated from Australian Acacia spp. Plant Soil 1991, 135, 109-120. [CrossRef]

51. Lafay, B.; Burdon, J.J. Molecular Diversity of Rhizobia Occurring on Native Shrubby Legumes in Southeastern Australia. Appl. Environ. Microbiol. 1998, 64, 3989-3997. [CrossRef] 
52. Leary, J.; Singleton, P.; Scowcroft, P.; Borthakur, D. Symbiotic diversity in the cosmopolitan genus Acacia. Symbiosis 2006, 41, 107-117.

53. Birnbaum, C.; Barrett, L.G.; Thrall, P.H.; Leishman, M.R. Mutualisms are not constraining cross?continental invasion success of Acacia species within Australia. Divers. Distrib. 2012, 18, 962-976. [CrossRef]

54. Velázquez, E.; Martínez-Hidalgo, P.; Carro, L.; Alonso, P.; Peix, A.; Trujillo, M.E.; Martínez-Molina, E. Chapter 10, Nodular endophytes: An untapped diversity. In Beneficial Plant Microbial Interactions: Ecology and Applications, 1st ed.; Bélen Rodelas Gonzalez and Jésus Gonzalez-Lopez: Boca Ratón, FL, USA, 2014; pp. 215-236.

55. Dourado, A.C.; Alves, P.I.L.; Tenreiro, T.; Ferreira, E.M.; Tenreiro, R.; Fareleira, P.; Crespo, M.T.B. Identification of Sinorhizobium (Ensifer) medicae based on a specific genomic sequence unveiled by M13-PCR fingerprinting. Int. Microbiol. 2009, 12, 215-225.

56. Diouf, D.; Samba-Mbaye, R.; Lesueur, D.; Ba, A.T.; Dreyfus, B.; De Lajudie, P.; Neyra, M. Genetic Diversity of Acacia seyal Del. Rhizobial Populations Indigenous to Senegalese Soils in Relation to Salinity and $\mathrm{pH}$ of the Sampling Sites. Microb. Ecol. 2007, 54, 553-566. [CrossRef]

57. Shiraishi, A.; Matsushita, N.; Hougetsu, T. Nodulation in black locust by the $\gamma$-proteobacteria Pseudomonas sp. and the $\beta$-proteobacteria Burkholderia sp. Systematic Appied. Microbiology 2010, 33, 269-274.

58. Saïdi, S.; Chebil, S.; Gtari, M.; Mhamdi, R. Characterization of root-nodule bacteria isolated from Vicia faba and selection of plant growth promoting isolates. World J. Microbiol. Biotechnol. 2013, 29, 1099-1106. [CrossRef]

59. Mårtensson, A.M.; Brutti, L.; Ljunggren, H. Competition between strains ofBradyrhizobium japonicum for nodulation of soybeans at different nitrogen fertilizer levels. Plant Soil 1989, 117, 219-225. [CrossRef]

60. Kiers, E.T.; Rousseau, R.A.; West, S.A.; Denison, R.F. Host sanctions and the legume-rhizobium mutualism. Nature 2003, 425, 78-81. [CrossRef] [PubMed]

61. Ferguson, B.; Mens, C.; Hastwell, A.; Zhang, M.; Su, H.; Jones, C.M.; Chu, X.; Gresshoff, P.M. Legume nodulation: The host controls the party. Plant Cell Environ. 2018, 42, 41-51. [CrossRef] [PubMed]

62. Dwivedi, S.L.; Sahrawat, K.L.; Upadhyaya, H.D.; Mengoni, A.; Galardini, M.; Bazzicalupo, M.; Biondi, E.G.; Hungria, M.; Kaschuk, G.; Blair, M.W.; et al. Advances in Host Plant and Rhizobium Genomics to Enhance Symbiotic Nitrogen Fixation in Grain Legumes. Adv. Agron. 2015, 129, 1-116. [CrossRef]

63. Fox, J. Interpreting the "selection effect" of biodiversity on ecosystem function. Ecol. Lett. 2005, 8, 846-856. [CrossRef]

64. Richardson, D.M.; Pyšek, P.; Rejmánek, M.; Barbour, M.G.; Panetta, F.D.; West, C.J. Naturalization and invasion of alien plants: Concepts and definitions. Divers. Distrib. 2000, 6, 93-107. [CrossRef]

65. Franche, C.; Lindström, K.; Elmerich, C. Nitrogen-fixing bacteria associated with leguminous and non-leguminous plants. Plant Soil 2008, 321, 35-59. [CrossRef]

66. Ding, H.; Hynes, M.F. Plasmid transfer systems in the rhizobia. Can. J. Microbiol. 2009, 55, 917-927. [CrossRef] 